\title{
HUBUNGAN LAMA PENGGUNAAN KONTRASEPSI IUD TERHADAP EFEK SAMPING IUD PADA AKSEPTOR IUD DI PUSKESMAS SUDIANG KOTA MAKASSAR
}

\author{
Ratna $^{1}$, Jamila kasim ${ }^{2}$ Ardolof Steny Termature ${ }^{3}$ \\ ${ }^{\text {I}}$ STIKES Nani Hasanuddin Makassar \\ ${ }^{2}$ STIKES Nani Hasanuddin Makassar \\ ${ }^{3}$ STIKES Nani Hasanuddin Makassar \\ Email:ns.ratna@stikesnh.ac.id ${ }^{1}$,Nersmila@ymail.com ${ }^{2}$,stenytermature21@gmail.com ${ }^{3}$ \\ Dikirim \\ Diterima \\ Diterbitkan \\ : 30 Juni 2020 \\ : 8 Agustus 2020 \\ : 3 September 2020
}

\begin{abstract}
IUD (Intra Uterine Device) is a contraception device that is inserted into the uterus, made of plastic material, some are wrapped with copper, and the shape is various. A common form and perhaps widely known by society is the form of a spiral. The purpose of this research is to know the relationship between the length of IUD use of side effects on IUD acceptor in the Sudiang Public Health Center in Makassar City. The design of the research used is quantitative descriptic research with the approach method that is in use is cross sectional. Sampling using accidental sampling with 58 respondents. Data collection is done using questionnaires and being embraced with a Chi square test $(P<$ $0.05)$. The results of the study showed obtained a P value of 0034 where $\alpha 0.05$ which means $p .<\alpha 0.05$ that there is a relationship between the length of use of IUD with the side effects of IUD on the acceptor in the Sudiang Public Health Center in Makassar City. It was concluded that there was a meaningful relationship between the length of use of IUD with side effects on IUD acceptor at Sudianag Public Health Center in Makassar City, where older users have more mild side effects and less experienced side effects of weight whereas New users are experiencing more severe side effects and fewer mild side effects.
\end{abstract}

Keywords: Duration of Use, IUD, Side Effects 


\section{PENDAHULUAN}

Masalah kependudukan merupakan masalah yang dihadapi oleh semua negara termasuk Indonesia. Di Indonesia masalah yang terjadi di bidang kependudukan adalah pertumbuhan penduduk yang masih tinggi. Semakin tingginya pertumbuhan penduduk maka semakin besar usaha yang dilakukan untuk mempertahankan kesejahteraan rakyat. Ancaman terjadinya ledakan penduduk di Indonesia semakin nyata. Indonesia merupakan negara ke 5 di dunia dengan estimasi jumlah penduduk terbanyak yaitu 249 juta. Di antara negara ASEAN, Indonesia dengan luas wilayah terbesar tetap menjadi negara dengan penduduk terbanyak, jauh di atas 9 negara lain. Salah satu usaha untuk menanggulangi masalah kependudukan tersebut adalah dengan mengikuti program Keluarga Berencana (KB). Program ini dimaksudkan untuk membantu pasangan dan perorangan dalam tujuan kesehatan reproduksi yang berkualitas. Selain itu melalui program ini dapat menurunkan Angka Kematian Ibu (AKI) dan Angka Kematian Bayi (AKB) serta penangulangan masalah kesehatan reproduksi dalam rangka membangun keluarga kecil berkualitas, dan untuk mempersiapkan kehidupan dalam mendukung kualitas generasi mendatang (Iis Rahayu \& Mohamad Reza 2018).

Menurut Nurul 2013 alat kontrasepsi IUD juga dapat menyebabkan efek samping antara lain gangguan menstruasi, benang IUD hilang (ekspulsi), keluar cairan berlebih dari vagina (keputihan). Efek samping kontrasepsi merupakan masalah bagi seorang akseptor yang memakainya, karena merupakan beban kejiwaan yang harus ditanggungnya, yang berakhir pada adanya kekhawatiran dan kecemasan yang berlebih, sehingga seorang akseptor akan mengalami kejadian drop out atau putus pakai (Margiyati \& Paryamtinah 2015). Menurut Saefuddin dkk, 2004 Efek samping umum yang mungkin terjadi adalah perubahan siklus haid (umumnya pada 3 bulan pertama dan akan berkurang setelah 3 bulan), haid lebih lama dan banyak, perdarahan (spooting) antar menstruasi, dan saat haid lebih sakit (Intan Riyadhul Zannah dkk, 2012).

Data dari WHO tahun 2015, penggunaan kontrasepsi telah meningkat di banyak bagian dunia, terutama di Asia dan Amerika Latin, namun di bagian sub-Sahara Afrika tetap terendah pemakaian kontrasepsi. Secara global, penggunaan kontrasepsi modern telah meningkat sedikit, dari 54\% di tahun 1990 menjadi 57,4\% pada tahun 2015. Secara regional, proporsi wanita berusia 15-49 melaporkan penggunaan metode kontrasepsi modern telah meningkat antara pada tahun 2008 dan 2015. Di Afrika itu naik dari 23,6\% menjadi 28,5\%, di Asia sedikit meningkat dari 60,9\% menjadi 61,8\%, dan di Amerika Latin dan Karibia tetap stabil di $66,7 \%$. 
Berdasarkan data yang diperoleh jumlah pasangan usia subur (PUS) di Indonesia pada tahun 2017 berjumlah 37.338.265 dengan jumlah peserta KB aktif 23.606.218 yang meliputi pengguna IUD berjumlah 1.688 .685 (7,15\%), Metode Operasi Wanita (MOW) berjumlah 655.762 (2,78\%), Metode Operasi Pria (MOP) berjumlah 124.262 (0,53\%), Implan berjumlah 1.650.227 (6,99\%), Suntik berjumlah 14.817.663 (62,77\%), Kondom berjumlah 288.388 (1,22\%) dan Pil 4.069.844 (17,24\%) (Kemenkes RI, 2018).

Salah satu alat kontrasepsi yang sering dipakai adalah IUD menurut BKKBN 2014 AKDR atau IUD atau Spiral adalah suatu benda kecil yang terbuat dari plastik yang lentur, mempunyai lilitan tembaga atau juga mengandung hormon dan dimasukan ke dalam rahim melalui vagina dan mempunyai benang (Mega \& Hidayat Wijayanegara, 2017). Berdasarkan Rrencana Pembangunan Jangka Menengah (RPJM) tahun 2004 2009 Departemen Kesehatan yang salah satu rencananya meningkatkan metode kontrasepsi jangka panjang yang salah satu metodenya adalah metode AKDR/IUD (Intan Riyadhul Zannah \& Ida Maryati, 2012).

Berdasarkan data yang diperoleh jumlah pengguna KB aktif di Makassar tahun 2015 berjumlah 179.137 dengan jumlah pengguna IUD sebanyak 9.254 (5,17\%), MOP sebanyak $77(0,04 \%)$, MOW sebanya $1.101(0,61 \%)$, Implan sebanyak $9.012(5,03 \%)$, Kondom berjumlah 5.476 (3,06\%), Suntik berjumlah 91.513 (51,09\%) dan Pil berjumlah 62.704 (35,00\%) (Dinas Kesehatan Sulawesi Selatan, 2016).

Berdasarkan data yang diperoleh jumlah penggunaan IUDCuT-380A aktif di Puskesmas Sudiang yang tercatat pada bulan September tahun 2017 adalah 701 pengguna, Sedangkan pada bulan Oktober tahun 2018 adalah 382 pengguna dan pengguna IUDCuT-380A aktif bulan April tahun 2019 adalah 403 orang pengguna aktif untuk daerah sudiang (Puskesmas Sudiang, 2019).

Berdasarkan pembahasan diatas tenatang efek samping penggunaan IUD, peneliti tertarik untuk mengetahui tentang hubungan lama penggunaan kontrasepsi IUD terhadap efek samping pada akseptor IUD di puskesmas Sudiang Kota Makassar.

\section{BAHAN DAN METODE}

\section{Lokasi, Populasi dan Sampel}

Desain penelitian yang digunakan adalah penelitian deskriptik kuantitatif dengan metode pendekatan yang di pakai adalah "cross sectional" yang mana adalah jenis penelitian yang menekankan waktu pengukuran /observasi data 
variabel independen dan dipenden hanya satu kali pada satu saat. Pada jenis ini, variabel independen dan dependen dinilai secara simultan pada suatu saat, jadi tidak ada tindak lanjut (Nursalam 2017).

Tempat dalam penelitian ini adalah Puskesmas Sudiang dan waktu penelitian ini adalah tanggal 12 Agustus - 24 Agustus 2019. Menurut Sastroasmoro dan Ismael, 2008 Populasi dalam penelitian adalah sejumlah subyek besar yang mempunyai karakteristik tertentu karakteristik subyek ditentukan sesuai dengan ranah dan tujuan penelitian (Susila dan Suyanto , 2015). Populasi pada penelitian ini adalah akseptor yang menggunakan IUD aktif yang berada pada puskesma Sudiang, dengan jumlah populasi sebesar 403 orang akseptor. Menurut Sastroasmoro dan Ismael, 2008 sampel adalah bagian dari populasi yang dipilih dengan cara tertentu hingga dianggap dapat mewakili populasinya (Suyanto 2015).

Teknik pengambilan sampel yang digunakan adalah secara sampling aksidental. Pada cara ini sampel diambil berdasarkan ketersediaan dan kemudahan mendapatkanya. Dengan kata lain sampel diambil/terpilih karena ada di tempat dan waktu yang tepat (Susila dan Suyanto, 2015) Sampel pada penelitian ini adalah 58 responden.

1. Kriteria inklusi dalam penelitian ini adalah:
a. Wanita usia subur 15-49 tahun
b. Akseptor KB IUDCuT-380A
c. Bersedia menjadi responden

2. Kriteria Eksklusi dalam penelitian ini adalah:
a. Tidak melengkapi data penelitian
b. Mengundurkan diri saat penelitian berlangsung

\section{HASIL DAN PEMBAHASAN}

1. Analisa Univariat

Tabel 1 Distribusi Responden Berdasarkan Lama Penggunaan IUD

\begin{tabular}{ccc}
\hline Lama Penggunaan & Frekuensi (f) & Persentase (\%) \\
\hline Baru & 23 & 39,7 \\
Lama & 35 & 60,3 \\
\hline Total & 58 & 100 \\
\hline
\end{tabular}


Jurnal Kebidanan Mutiara Mahakam, Vol 8 , No 2, Tahun 2020, Hal 84-93

Berdasarkan tabel 1 diatas diketahui bahwa kelompok responden yang paling banyak adalah dengan penggunaan lama sebanyak 35 responden $(60,3 \%)$ dan penggunaan baru sebanyak 23 responden $(39,7 \%)$.

Tabel 2 Distribusi Responden Berdasarkan Efek Samping Penggunaan IUD

\begin{tabular}{ccc}
\hline Efek Samping Penggunaan IUD & $\mathrm{n}$ & $\%$ \\
\hline Ringan & 25 & 43,1 \\
Berat & 33 & 56,9 \\
\hline Total & 58 & 100 \\
\hline
\end{tabular}

Berdasrakan tabel 2 di atas diketahui bahwa kelompok responden yang paling banyak adalah kelompok responden dengan efek samping berat sebanyak 33 responden $(56,9 \%)$ dan yang terendah adalah dengan efek samping ringan sebanyak 25 responden $(43,1 \%)$.

2. Analisa Bivariat

Untuk melihat hudungan antara lama penggunaan dengan efek samping penggunaan IUD di wilayah kerja Puskesmas Sudiang, maka digunakan Descriptive Statistics Crosstabs menggunakan uji Chi Square Test berdasarkan Correction Pearson Chi Square dengan toleransi kesalahan sebesar 5\% ( $\alpha$ 0.05). Maka ketentuan bahwa lama penggunaan IUD mempunyai hubungan yang signifikan dengan efek samping pada akseptor IUD di Puskesmas Sudiang apabila $p<\alpha 0.05$. Penjelasannya dapat di liahat pada tabel berikut ini.

Tabel 3 Hubungan Lama Penggunaan IUD dengan Efek Samping IUD pada Akseptor Di Puskesmas Sudiang Kota Makassar

\begin{tabular}{ccccccc}
\hline Lama & \multicolumn{9}{c}{ Efek Samping IUD } & \multicolumn{2}{c}{ Jumlah } \\
\cline { 2 - 6 } Penggunaan & \multicolumn{3}{c}{ Ringan } & \multicolumn{2}{c}{ Berat } & \multicolumn{2}{c}{ n } \\
\cline { 2 - 6 } IUD & $\mathrm{n}$ & $\%$ & $\mathrm{n}$ & $\%$ & $\%$ \\
\hline Baru & 6 & 26,1 & 17 & 73,9 & 23 & 39,6 \\
Lama & 19 & 54,3 & 16 & 45,7 & 35 & 60,3 \\
Jumlah & 25 & 43,1 & 33 & 56,9 & 58 & 100 \\
\hline \multicolumn{6}{c}{$\alpha=0,05$} & $p=0,034$ \\
\hline
\end{tabular}

Dari tabel 3 di atas maka, dapat diketahui bahwa dari 23 responden dalam kategori pengguna IUD baru, didapatkan bahwa sebanyak 6 responden yang 
mengalami efek samping IUD ringan dan sebanyak 17 responden yang mengalami efek samping IUD berat. Sedangkan dari total 35 responden dalam kategori pengguna IUD lama, terdapat 19 responden yang mengalami efek samping IUD ringan dan 16 reponden lainnya mengalami efek samping IUD yang berat.

Setelah dilakukan analisis uji menggunakan Chi Square Test, berdasarkan Pearson Chi Square maka diperoleh nilai $p$ value sebesar 0.034 dimana $\alpha 0.05$ yang berarti $p<\alpha 0.05$. Oleh karena itu Ha yang menyatakan bahwa terdapat hubungan antara lama penggunaan IUD dengan efek samping IUD di Puskesmas Sudiang Kota Makassar dinyatakan Ha diterima dan Ho ditolak.

Hasil penelitian menunjukan bahwa responden terbanyak berada pada kisaran umur 31 sampai 40 tahun dengan jumlah 26 responden. Menurut Fischl (2007) problem utama pada pemakian IUD diatas 35 tahun adalah perdarahan, diajurkan untuk mengaangkat IUD jika terdapat perdarahan dan nyeri pada perempuan di atas 35 tahun, hal ini mencegah terjadinya anemia dan infeksi serta keterlambatan diagnostik adanya kesalahan organik (Asria and Nurullita 2013).

Dari hasil penelitian menunjukan bahwa jenjang pendidikan responden yang terbanyak adalah SMA dengan jumlah 32 responden yang berarti pengetahuan relaif bagus, pengetahuan tentang IUD yang meliputi cara kerja, keuntungan, kerugian serta efek sampingnya diperoleh dari bidan pada saat pemeriksaan kehamilan atau pada saat pemasangan IUD.

Hasil penelitian menunjukan bahwa pekerjaan responden yang paling dominan adalah ibu rumah tangga dengan jumlah 43 responden. Orang yang memiliki pekerjaan yang lebih layak guna pemenuhan semua kebutuhan hidupnya juga memiliki kecenderugan untuk memiliki tingkat kesehatan dan perilaku kesehatan yang lebih baik dari pada orang yang memiliki tingkat pekerjaan yang lebih rendah dengan asumsi memiliki kebutuhan hidup yang sama, oleh sebab itu seseorang yang memiliki pekerjaan yang layak akan lebih memperhatikan perilaku kesehatan untuk diri sendiri dan lingkunganya (Asria and Nurullita 2013).

Dari penelitian ini dapat dilihat bahwa akseptor IUD yang baru lebih domain mengalami efek samping yang berat hal ini disebabkan karena tubuh 
masih beradaptasi dengan IUD yang dipakai sedangkan pada penggunaan lama lebih domain mengalami efek samping yang ringan hal ini disebabkan karena tubuh sudah beradptasi dengan IUD yang digunakan. Efek samping yang terjadi adalah perubahan siklus menstruasi, perubahan jumlah darah menstruasi, keputihan, spooting, gangguan dalam hubungan seksual dan eksplusi.

Menurut Damayanti dan Endang Herliyati (2003) penggunaan alat kontrasepsi dalam rahim (AKDR), dapat menimbulkan terjadinya reaksi terhadap benda asing dan memicu pertumbuhan jamur kandidas yang semula saprofit menjadi patongen sehingga terjadi kandidiasis vagina dengan gejala timbulnya keputihan (Mustika Ratnaningsih Purbowati 2015).

Teori yang di kutip dari penelitian Siswati (2011) ketidak nyamanan dalam berhubungan seksual dapat terjadi seringkali karena wanita merasa sakit atau tidak nyaman ketika berhubungan seksual. Penggunaan AKDR dapat berpengaruh pada kenyamanan seksual karena efek samping spiral bisa menimbulkan perdarahan hebat, nyeri kejang diperut bawah atau mengganggu suami jika menggunting benang spiral kurang cukup pendek. Jika benang spiral terlalu panjang menjuntai suami merasa terganggu setiap kali bersenggama, sehingga sering mendorong istri untuk melepaskan spiral dan minta menggantinya dengan kontrasepsi lain (Siswati, 2011).

Teori lain yang dikutip dari penelitian Dwi Puspitasari dan Warsiti (2012) teori yang menyatakan bahwa efek samping dari penggunaan alat kontrasepsi IUD antara lain haid lebih banyak dan lama. Ketika masa haid, darah yang keluar menjadi lebih banyak karena terjadi peluruhan dinding rahim. Proses ini menimbulkan perlukaan di daerah rahim, sehingga apabila IUD mengenai daerah tersebut, maka akan menambah volume darah yang keluar pada masa haid. Darah yang keluar bisa dibedakan, biasanya jika spotting, yang keluar adalah berwarna kecoklatan, sedangkan pada saat haid, darah akan berwarna merah segar (Dwi Puspitasari dan Warsiti, 2012).

Penelitian Radicha Nur widyaningtyas dan kawan kawan(2015)tentang hubungan umur dan lama penggunaan IUD dengan efek samping penggunaan 
IUD menyatakan bahwa adanya hubungan lama penggunaan dengan efek sampin perubahan pola menstruasi dengan $\mathrm{p} 0,028<\alpha 0,05$.

Penelitian yang dialakuakan Mustika Ratnaningsih Purbowati (2015)tentang pengaruh penggunaan IUD terhadap penyakit keputihan di Puskesmas Kebasan Kabupaten Banyumas di dapatkan ada hubungan yang bermakna antara lamanya penggunaan IUD dengan kejadian keputihan dengan p $0,002<\alpha 0,05$.

Penelitian yang dilakukan Siswati (2011) hubunganlamapenggunaanintra uterine device (IUD) dengankenyamanan seksual diPuskesmas Simo Kabupaten Boyolali menyatakan bahwa nilai Chi-Square hitung 10,804 lebih besar daripada 3,84 dengan $\mathrm{p}$ value sebesar $0,01(<0,05)$. Dengan demikian Ada hubungan antara lama penggunaan IUD dengan kenyamanan seksual.

Setelah melihat hasil dari penelitian, maka dengan membandingkan beberapa teori terkait dan penelitian sebelumnya yang sejalan berdasarkan hal tersebut, maka peneliti berasumsi bahwa lama penggunaan IUD memiliki hubungan yang signifikan dengan efek samping yang terjadi pada akseptor IUD. Dengan penggunaan baru lebih domain terkena efek samping yang berat sedangkan penggunaan lama lebih domain terkena efek samping yang ringan hal ini mungkin terjadi karena adanya adaptasi dari tubuh dengan IUD yang digunakan.

\section{SIMPULAN}

Berdasarkan hasil penelitian disimpulkan bahwa ada hubungan bermakna antara lama penggunaan IUD dengan efek samping pada akseptor IUD di Puskesmas Sudiang Makassar, dimana pengguna lama lebih banyak mengalami efek samping ringan dan lebih sedikit mengalami efek samping berat sedangkan pengguna baru lebih banyak mengalami efek samping berat dan lebih sedikit menglami efek samping ringan.

\section{DAFTAR PUSTAKA}

World Health Organization. (2015). Nutrition Landscape Information System (NLIS) Country People Profile Indicators : Interpretation Guide.Geneva.

Asria, Wa and Ulfa Nurullita. (2013). "Gambaran Pola Menstruasi Pada Akseptor Intra 
Jurnal Kebidanan Mutiara Mahakam, Vol 8 , No 2, Tahun 2020, Hal 84-93

Uterin Device (IUD) DI Wilayah Kerja Puskesmas Kedungmundu Semarang." $1(1): 28-36$.

Dinkes, Sulawesi Selatan. (2016). "Data Profil Dinkes Kab/Kota Se Sulsel Tahun 2015."

Dwi Puspitasari \& Warsiti. (2012). Gambaran Kejadian Efek Samping Pemakaian Iud Pada Akseptor Kb Iud Di Desa Ambarketawang Gamping Sleman Tahun 2011. Tugas Akhir thesis, Universitas 'Aisyiyah Yogyakarta.

Iis Rahayu, Mohamad Reza, Elly Usman. (2018). "Hubungan Pengetahuan Ibu Pasangan Usia Subur Dengan Penggunaan Kontrasepsi IUD Di Nagari Andalas Baruh Bukit Kecamatan Sungayang Kabupaten Tanah Datar." Jurnal Kesehatan Andalas 7:4447.

Intan Riyadhul Zannah, Ida Maryati, Restuning Widiasih. (2012). "Gambaran KeluhanKeluhan Akibat Penggunaan Alat Kontrasepsi Iud Pada Akseptor Iud Di Wilayah Kerja Puskesmas Sukajadi Kota Bandung." 1-20.

Margiyati and Paryamtinah. (2015). "Gambaran Kejadian Efek Samping Penggunaan Alat Kontrasepsi Intra Uterine Device (IUD).”

Mayangsari, R. N., Saidah, S., \& Lidia, B. (2019). Hubungan Akseptor Kb Iud Dengan Kejadian Keputihan Di Puskesmas Jetis Kota Yogyakarta. Jurnal Kebidanan Mutiara Mahakam, 7(1), 18-25. https://doi.org/10.36998/jkmm.v7i1.37

Mega, Hidayat Wijayanegara. (2017). Asuhan Kebidanan Keluarga Berencana Dilengkapi Dengan Soal-Soal Uji Kompetensi Bidan. edited by H. M. Sutisna. Jakarta: Trans Info Media.

Mustika Ratnaningsih Purbowati, Dyah Retnani Basuki. (2015). "Pengaruh Penggunaan IUD Terhadap Penyakit Keputihan Di Puskesmas Kabupaten Banyumas." MEDISAINS Jurnal Ilmiah Ilmu-Ilmu Kesehatan 13(3):20-28.

Nursalam. (2017). Metodologi Penelitian Ilmu Keperawatan: Pendekatan Praktis. 4th ed. edited by P. P. Lestari. Jakarta: Salemba Medika.

Radicha Nur widyaningtyas, Heni puji wahyuningsih, Dwiana Estiwidani. 2015. "HUBUNGAN UMUR DAN LAMA PENGGUNAAN IUD DENGAN EFEK SAMPING PENGGUNAAN IUD.” Kesehatan Ibu Dan Anak 8(2):18-23.

Kementrian Kesehatan RI. (2018, November 2). Potret Sehat Indonesia dari Riskesdas 2018. Potret Sehat Indonesia dari Riskesdas 2018, p. . Retrieved January 2019, from depkes.go.id/article/view/18110200003/potret-sehat-indonesia-dari-riskesdas2018.html

Siswati, Ani Nur Fauziah \& Bayu Ika. (2011). "Hubungan Lama Penggunaan Intra Uterine Device (IUD) Dengan Kenyamanan Seksual Di Puskesmas Simo Kabupaten Boyolali Periode Januari - Juni Tahun 2011.”32-46. 
Jurnal Kebidanan Mutiara Mahakam, Vol 8 , No 2, Tahun 2020, Hal 84-93

Susila \& Suyanto. (2015). Metodologi Penelitian Cross SectionalKedokteran dan Kesehatan. Klaten: BOSSSCRIPT 